\title{
OBSERVATIONS ON THE POPULATION ECOLOGY OF THE CAVE SALAMANDER, EURYCEA LUCIFUGA (RAFINESQUE, 1822)
}

\author{
J. Gavin Bradley ${ }^{1}$ and Perri K. Eason ${ }^{2}$
}

\begin{abstract}
Salamanders are potentially important constituents of subterranean ecosystems, but relatively little is known about their effects in caves. A common facultative hypogean salamander in the eastern United States is the Cave salamander, Eurycea lucifuga (Rafinesque, 1822). Despite being common and widespread, little more than basic information exists for this species. Herein, we provide new data concerning open population modeling, demographics, wet-biomass, and density estimation for a population in a small Kentucky spring cave. We have found population abundances of this species to be much higher than previously reported, and describe low capture probabilities and high survival probabilities. Average wet-weight per individual was $2.90 \mathrm{~g}$, and estimated seasonal population wet-biomass peaked at $1426.8 \mathrm{~g}$. Mean salamander density and wet-biomass density are 0.08 salamanders $\mathrm{m}^{-2}$ and $0.22 \mathrm{~g} \mathrm{~m}^{-2}$, respectively. The data we provide indicate that Cave salamanders have important ecological impacts on small spring cave systems.
\end{abstract}

\section{Introduction}

The Cave salamander, Eurycea lucifuga (Rafinesque, 1822), is a facultative cave dweller that is native to the eastern United States (Hutchison, 1958; Williams, 1980; Petranka, 1998; Camp et al., 2014). The classification scheme of cave-dwelling organisms is in flux due to a lack of consensus for terminology that defines the gradations of dependency that organisms have on cave environments. Troglobites, or troglobionts, are wholly dependent upon cave environments and cannot persist outside of them. Facultative cave-dwelling organisms may be broadly defined as troglophilic and trogloxenic. Troglophiles are able to persist entirely in or outside of caves, whereas trogloxenes are frequently found in caves but must leave at some point during their life cycle to obtain one or more epigean resources. Eurycea lucifuga must leave caves to obtain sufficient food resources from surface environments, but may otherwise persist in subterranean environments. Under the classical troglobite-troglophile-trogloxene-accidental scheme (e.g., Barr Jr. 1968; Barr and Holsinger 1985; Trajano and Carvalho 2017), E. lucifuga is classified as a trogloxene. A slightly different classification scheme has been suggested recently: troglobiont-eutroglophile-subtroglophile-trogloxene (e.g., Lanza et al. 2006; Sket 2008; Lunghi et al. 2014) according to which E. lucifuga is classified as a subtroglophile. Categories of these two classification schemes (classic versus newer) are somewhat synonymous: troglobite is synonymous with troglobiont, troglophile is similar to eutroglophile, trogloxene is similar to subtroglophile, and accidental is similar to trogloxene. However, there are discrepancies within the two naming systems as to the meaning of troglophile and trogloxene, leading to confusion of these terms. Therefore, here we simply refer to E. lucifuga as a facultative cave-dwelling organism, one that is dependent upon epigean food resources.

Cave salamanders are relatively common, but little more than some natural history, morphology, physiology, taxonomy, behavior, and basic ecological information exists for this species. Cave salamanders may be important constituents of subterranean ecosystems, since salamanders are generally considered to be key ecological components in certain ecosystems (Davic and Welsh, 2004; Semlitsch et al., 2014). We collected data on a population of Cave salamanders from a Kentucky cave to report basic demographic information, and to calculate seasonal abundance estimates, capture probabilities, and survival probabilities using open-population models. These abundances were used to estimate seasonal wet-biomass, and we estimated wet-biomass density and salamander density from the same cave. This represents the first approximation of these characteristics for this species.

Population modeling and estimates of biomass and density provide important species information, which facilitates a greater understanding of the ecological influence a species has in its ecosystem. This is important because the impact of cave-dwelling salamanders on cave ecosystems is poorly understood. Populations of obligate cave species (i.e., troglobites) are typically small, due to the lack of available energy within their habitat (Venarsky et al., 2014). However, facultative cave species, such as Cave salamanders, use the epigean environment, where abundant energy is accessible, likely supporting larger populations of these organisms. This may have great implications for cave ecosystem dynamics. Estimates of population model parameters, biomass, and density of facultative cave-dwelling salamanders may provide important insights that can inform cave ecology and conservation.

${ }^{1}$ Elizabethtown Community and Technical College, Biology Department, 600 College Street Road, Elizabethtown, KY 42701, jbradley0127@kctcs.edu ${ }^{2}$ University of Louisville, Department of Biology, Life Sciences Building, Room 139, Louisville, KY 40208, perri.eason@louisville.edu 


\section{Methods}

We monitored a population of E. lucifuga in two mostly crawlway-sized passages, $99 \mathrm{~m}$ (main passage) and $82.3 \mathrm{~m}$ (side passage), of Sauerkraut Cave, a small spring cave in E.P. "Tom" Sawyer State Park, Louisville, Kentucky, USA. (Specific location details are not given in an effort to reduce potential disturbance and vandalism to the cave, but may be obtained upon request from the Kentucky Speleological Survey). This cave was historically used as a springhouse, and was modified extensively with the construction of troughs and brick walls that spanned much of the entrance (Ford and Ford, 1882). The perennial stream was channelized to the west side of the main passage through a brick trough. The water exits the cave, then is immediately routed underground by a pipe.

Surveys were generally conducted weekly from March 2015 to February 2017, but survey dates were modified occasionally due to flooding or scheduling difficulties. In each passage, we searched the walls, floor, ceiling, and standing water for terrestrial (adult and juvenile) salamanders using red-filtered light during daylight hours (typical start time between 1100 to 1230). Hutchison (1958), Williams (1980), and Briggler and Prather (2006) similarly conducted surveys of this species during daylight hours. We counted all individuals found and used an Olympus TG-4 digital camera (Olympus America Inc., Center Valley, Pennsylvania, USA) to photograph the dorsal spot pattern of the head and neck of each salamander in plain sight. These images were used for individual identification in the pattern-recognition software Interactive Individual Identification System-Spot version 4.0.2 (I3S-S) (van Tienhoven et al., 2007; den Hartog and Reijns, 2014). This method of individual identification has been found to be successful for this species (Bradley and Eason, 2018) and closely related E. longicauda longicauda (Jonas et al., 2011; Nazdrowicz, 2015). We also photographed the entire dorsal surface of individuals next to metered tape to create scaled images. From these images we measured snout-furrow length (SFL), a body metric similar to snout-vent length (SVL) (unpublished data, Bradley), in millimeters ( \pm SE) using image analysis software, Image $1.48 \mathrm{v}$ (Schneider et al., 2012). We determined gender by secondary sexual characteristics (males: swollen mental gland and elongated oral cirri; females: ovaries visible through the body wall) that are particularly evident from July to November. Additionally, we estimated age classes (adult and juvenile) by SFL; referencing measurements of SVL at sexual maturity, reported by Hutchison (1966) and Carlyle et al. (1998) for Cave salamanders, we classified individuals $\geq 49 \mathrm{~mm}$ SFL as adults.

Summary statistics are presented as the mean ( \pm SE). A $X^{2}$ goodness-of-fit test was conducted using $R$ statistical software 3.4.1 (R Core Team, 2017) to determine if the observed sex ratio of this population differed $(\alpha=0.05)$ from the expected 1:1 ratio. We estimated population parameters (i.e., abundance, capture and survival probabilities) using recapture histories in open (Jolly-Seber) population models. Open population models allow births, deaths, immigration and emigration to occur, and are more realistic for long-term studies. The repeated surveys resulted in recapture histories for those individuals that were seen and marked (i.e., photographed) more than once. We conducted model estimation by season: spring (March to May), summer (June to August), fall (September to November), and winter (December to February). Population models were analyzed using Rcapture (Baillargeon and Rivest, 2007) in R. We assessed model fit with Akaike Information Criterion and by refitting models with Pearson residuals $\geq 2$ (Baillargeon and Rivest, 2007; Beck et al., 2013). Estimates for each sampling period within a season were pooled to provide a single mean $( \pm$ SE) value of each parameter for each season.

To estimate salamander population biomass, we modified the equation $W=a S V L^{b}$ (Salvido, 1998; Huntsman et al., 2011) by substituting SVL with SFL (i.e., $W=a S F L^{b}$ ), to calculate individual salamander weight (W). For estimating the constants, $a$ and $b$, we collected, weighed, and measured salamanders from March to April 2017, after the original study period. For these salamanders, we measured SFL as described above using ImageJ. To obtain individuals' W, we directed salamanders by hand, or an aquarium net, into a tared, plastic bag containing a paper towel wetted with cave water and then weighed them in grams ( \pm SE) using a Pesola Micro-Line spring scale. We then released them at the site of capture. Also, we noted gender during this procedure, using similar sexual characteristics as described above; individuals too small to exhibit sexual characteristics were classified as juveniles. Capture and handling followed guidelines by Shaffer et al. (1994), HACC (2004), and Stasiak (2015).

We developed regressions (predictor variable $=$ SFL; response variable $=$ W) for males $(n=36)$, females $(n=20)$, and juveniles $(n=4)$, using log-transformed data for preliminary comparisons to determine whether there were differences in regressions between males vs. females and adults vs. juveniles. We analyzed these comparisons using ANCOVA in R. Since no significant differences in the relationship between SFL and W were detected among groups (see Results), one common regression equation was developed using non-log-transformed data. We used that equation and SFL measurements acquired from March 2015 to February 2017 to estimate individuals' W for the study population. Next, we calculated the mean individual W, then multiplied the mean W by seasonal abundances to estimate seasonal wet-biomass, following Salvidio (1998) and Crawford and Peterman (2013). We estimated mean ( \pm SE) wet-biomass density $\left(\mathrm{g} \mathrm{m}^{-2}\right)$ by first multiplying mean $\mathrm{W}$ by the mean salamander count, then dividing this number by the available surface area of the walls and floor of the cave. Subsequently, we estimated mean ( \pm SE) salamander density (salamanders $\mathrm{m}^{-2}$ ) by dividing the mean salamander count by the same available cave surface area. 


\section{Results}

The mean salamander count per survey was $66.10 \pm 4.00$ (range: 10 to $245 ; n=73$ ) and the mean number of salamanders photographed per survey was $38.40 \pm 2.97$ (range: 0 to $172 ; n=72$ ), with a total of 1127 individual salamanders identified. The numbers of individuals identified as males and females were 97 and 106, respectively. The sex ratio is 1:1.1, which does not deviate significantly from a 1:1 ratio $\left(\mathrm{X}^{2}=0.40 \mathrm{df}=1, p=0.528\right)$. Mean SFL was 55.26 $\pm 0.41 \mathrm{~mm}$ (range: 25.84 to $74.77 ; \mathrm{n}=380$ ) in study year one (March 2015 to February 2016), with 80.3\% of captured individuals sexually mature ( $\geq 49 \mathrm{~mm}$ SFL). Similarly, mean SFL was $56.82 \pm 0.37 \mathrm{~mm}$ (range: 35.95 to $73.91 ; \mathrm{n}=364$ ) in study year two (March 2016 to February 2017), with 81.6\% $\geq 49 \mathrm{~mm}$ SFL. Open population models revealed that salamander abundance was highest in spring 2016, with the maximum abundance estimated at $492 \pm 77.2$ individuals (Table 1, Fig. 1).

Capture probabilities (Table 1) were correspondingly low in spring 2016 (0.04 \pm 0.01 probability); the probability of being captured in the cave was also relatively low in summer (0.13 in 2015 and 2016), but higher in fall and win-

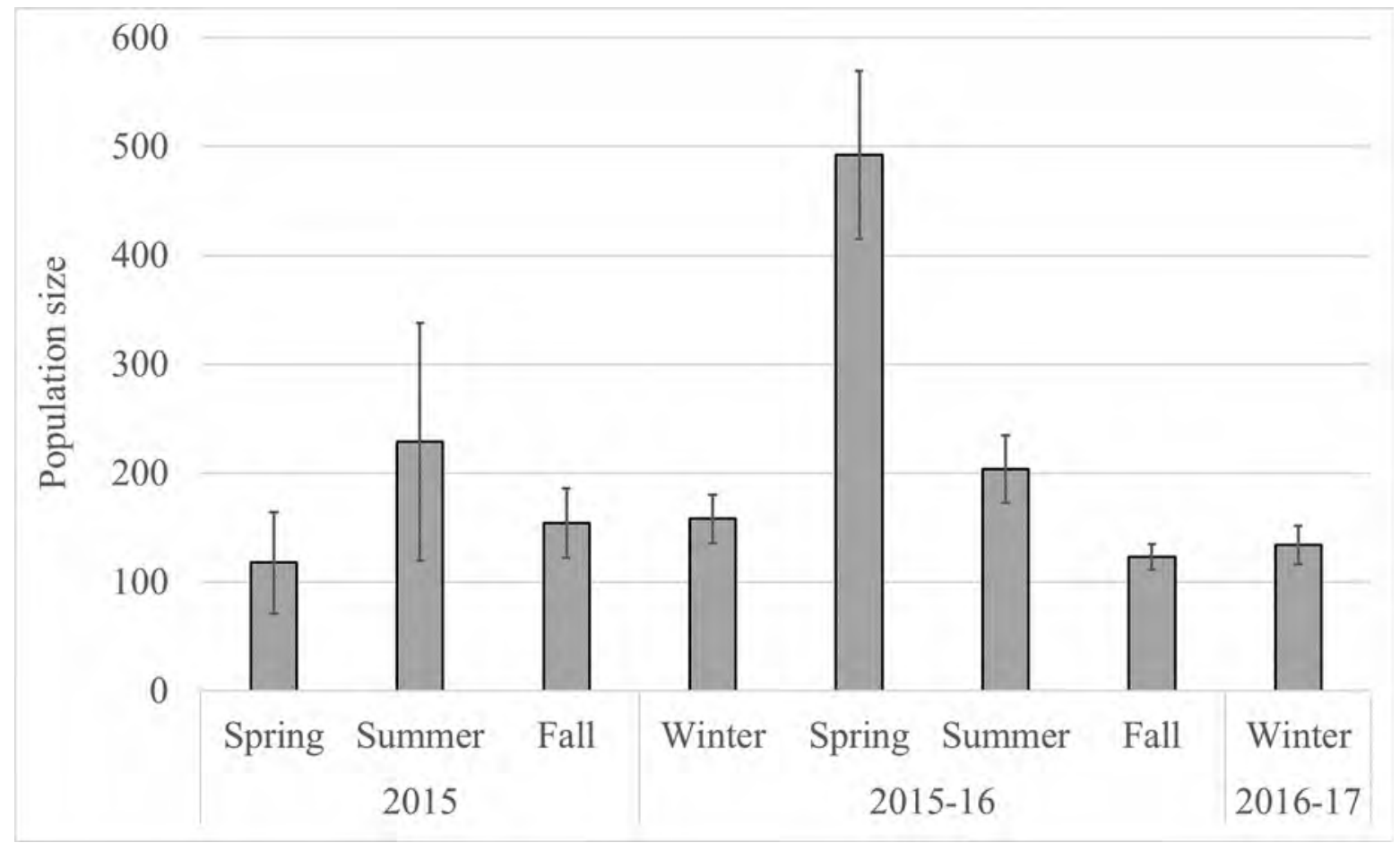

Figure 1. Seasonal estimates of the population size ( \pm SE) of Cave salamanders in Sauerkraut Cave in from 2015 to 2017.

Table 1. Parameters calculated in open population models in the Rcapture package of R. Values are presented as the mean \pm SE.

\begin{tabular}{ccccc}
\hline Season & Year & Abundance & Capture Probability & Survival Probability \\
\hline Spring & 2015 & $118 \pm 46.5$ & $0.068 \pm 0.029$ & $0.923 \pm 0.095$ \\
Summer & 2015 & $229 \pm 109$ & $0.126 \pm 0.063$ & $0.961 \pm 0.352$ \\
Fall & 2015 & $154 \pm 31.8$ & $0.204 \pm 0.048$ & $0.709 \pm 0.063$ \\
Winter & $2015-16$ & $158 \pm 22.6$ & $0.227 \pm 0.032$ & $0.858 \pm 0.043$ \\
Spring & 2016 & $492 \pm 77.2$ & $0.038 \pm 0.010$ & $0.930 \pm 0.024$ \\
Summer & 2016 & $204 \pm 31.1$ & $0.127 \pm 0.024$ & $0.798 \pm 0.040$ \\
Fall & 2016 & $123 \pm 11.8$ & $0.292 \pm 0.038$ & $0.730 \pm 0.037$ \\
Winter & $2016-17$ & $134 \pm 17.8$ & $0.208 \pm 0.029$ & $0.850 \pm 0.026$ \\
\hline
\end{tabular}

ter (range: 0.20 to 0.29). Probability of survival was high in spring and summer 2015 and spring 2016 (range: 0.92 to 0.96) and lowest in fall (0.71 and 0.73 for 2015 and 2016, respectively).

Regressions of SFL and W showed that the relationship between length and weight did not differ significantly in either males vs. females or adults vs. juveniles ( $F$ $=0.37, \mathrm{df}=1, p$ $=0.55$ for males vs. females; $F=$ 1.58, $\mathrm{df}=1, p=$ 0.21 for adults vs. juveniles). Thus, we used a common regression line for all individuals, $\mathrm{W}=$ $0.0155($ SFL) 3.0042 (Fig. 2). Mean calculated W for salamanders with measured

SFL from March 2015 to February 2017 was $2.90 \pm 0.042 \mathrm{~g}$ (range: 0.27 to $6.31 \mathrm{~g} ; \mathrm{n}=649$ ). Estimates of seasonal wet-biomass (Table 2) showed high biomass in spring 2016 and relatively low biomass in fall and winter, as would be expected given the numbers of salamanders seen during respective surveys.

The total available surface area of walls and floor in Sauerkraut Cave is $853.4 \mathrm{~m}^{2}$ (main passage: $468.8 \mathrm{~m}^{2}$; side passage: $384.6 \mathrm{~m}^{2}$ ). Mean wet-biomass density was $0.22 \pm 0.014 \mathrm{~g} \mathrm{~m}^{-2}$ (range: 0.03 to $0.83 ; \mathrm{n}=73$ ). Mean sal- 


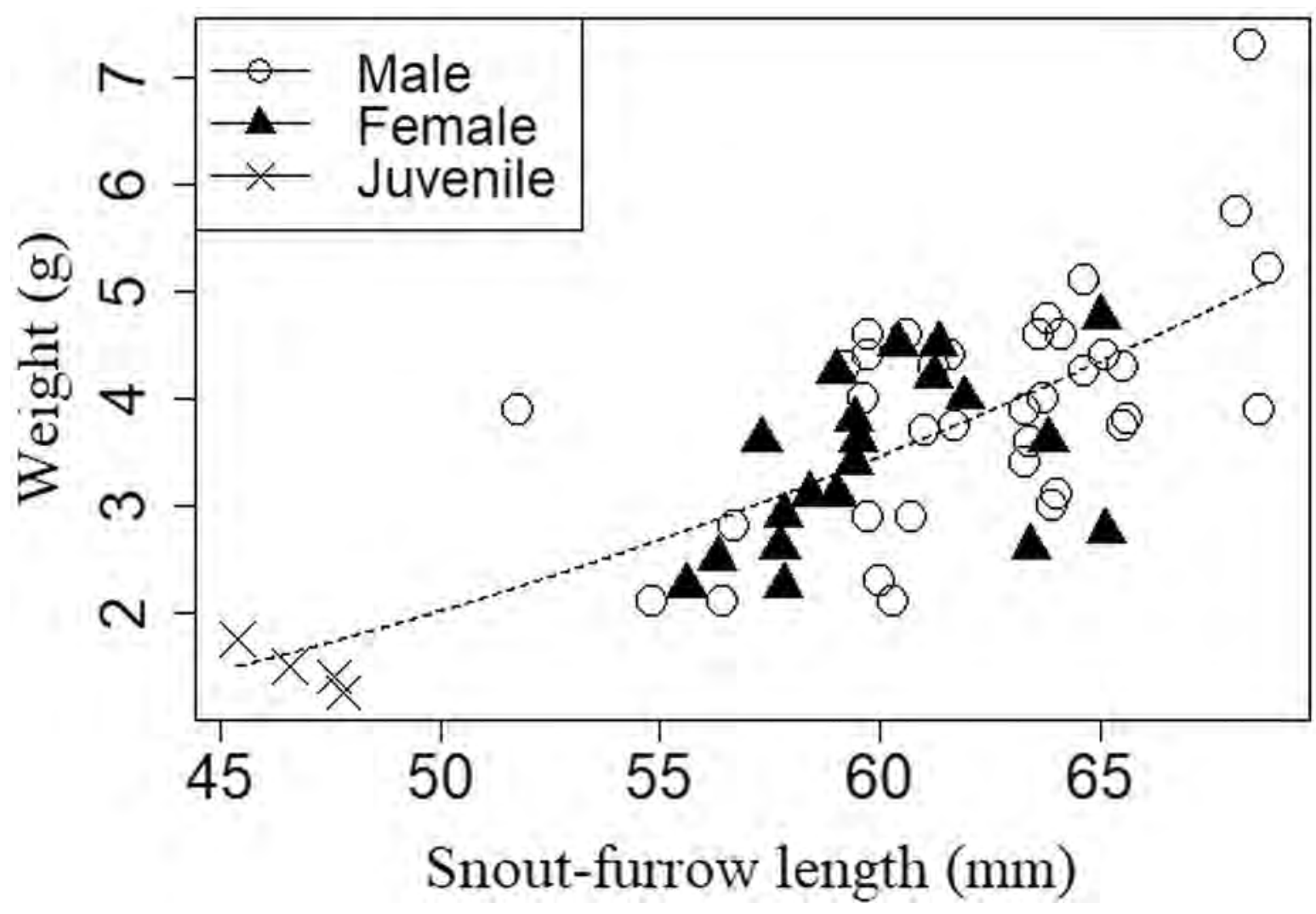

Figure 2. Scatterplot and power trendline, $W=0.0155(S F L)^{3.0042}$, for the relationship between $S F L$ and $W$ for male, female, and juvenile Cave salamanders.

Table 2. Estimates of seasonal population wet-weight biomass for Cave salamanders at Sauerkraut Cave.

\begin{tabular}{ccc}
\hline Season & Year & $\begin{array}{c}\text { Wet-Weight } \\
\text { Biomass, g }\end{array}$ \\
\hline Spring & 2015 & 342.2 \\
Summer & 2015 & 664.1 \\
Fall & 2015 & 446.6 \\
Winter & $2015-16$ & 458.2 \\
Spring & 2016 & 1426.8 \\
Summer & 2016 & 591.6 \\
Fall & 2016 & 356.7 \\
Winter & $2016-17$ & 388.6 \\
\hline
\end{tabular}

. He suggested that gravid females may become less active and/o more secluded than males during the breeding season to explain part of this bias. However, Hutchison (1958) sampled 11 months out of one year and consistently found more males than females regardless of season. No evidence was found in this study to support Hutchison's suggestion. Mean snout-furrow length (SFL) for this population of Cave salamanders is similar to snout-vent length measures reported by Hutchison (1958), Williams (1980), Carlyle et al. (1998) and Juterbock (2005) for other Cave salamander populations. Mean SFL and the proportion of salamanders $\geq 49 \mathrm{~mm}$ SFL indicates adults are numerically dominant in this population with a relatively low presence of juveniles (19.7\% in study year one and $18.4 \%$

Table 3. Wet-weight biomass density and salamander density of Cave salamanders in Sauerkraut Cave.

Passage $\quad$ Wet-Weight Biomass Density $\left(\mathrm{g} \mathrm{m}^{-2}\right)$

\begin{tabular}{|c|c|c|c|c|c|c|c|}
\hline & & \multicolumn{3}{|c|}{$\left(\mathrm{g} \mathrm{m}^{-2}\right)$} & \multicolumn{3}{|c|}{ (individuals $\mathrm{m}^{-2}$ ) } \\
\hline & & Mean & SE & Range & Mean & SE & Range \\
\hline Main & 76 & 0.34 & 0.022 & $0.04-1.37$ & 0.12 & 0.007 & $0.01-0.47$ \\
\hline Total & 73 & 0.22 & 0.014 & $0.03-0.83$ & 0.08 & 0.005 & $0.01-0.29$ \\
\hline
\end{tabular}
in study year two). Juveniles c $\mathrm{O}$ p o s e d $11.35 \%$ of marked individuals in Hutchison (1958), and Nazdrowicz (2015) found that juveniles of E. I. longicauda comprised 11 to $35 \%$ of total populations. This pattern is characteristic of other plethodontid salamanders as well (Hairston Sr., 1987).

To our knowledge, this study provides the first estimates of abundance using open population models for $E$. lucifuga, and the first account of capture and survival probabilities for this species. Previously, Hutchison (1958) provided esti- 
mates of population size for E. lucifuga using a closed (Lincoln-Peterson) population model. His estimates of population size (36 to 63 individuals from four caves in Virginia, USA) are low compared to ours, likely because he only sampled from the twilight zone of his study caves. Eurycea lucifuga is known to inhabit both the dark and twilight zones of caves (Green et al., 1967), and population distribution patterns change seasonally within these zones (Hutchison, 1958; Williams, 1980; Camp et al., 2014). Our observations in the dark zone of Sauerkraut Cave indicated that a substantial proportion of the population occurs there depending upon the time of year. Hutchison (1958) also pooled counts and recaptures for his entire study year. This practice violates the assumption of closure and, thus, results in poor model estimation. He acknowledged the inadequacies of using this model, suggesting rough estimates at best. We have found that population size estimates for cave-inhabiting $E$. lucifuga may be much larger, and probably more accurate, when individuals from both the dark and twilight zones are included in open population modeling. We believe our estimates are reasonable because they are within range of estimates for other species of salamanders occupying caves (Huntsman et al., 2011; Fenolio et al., 2014; Taylor et al., 2015) or similar habitats, i.e., springhouses (Nazdrowicz, 2015) and wet rock faces (Salvidio, 1998; Crawford and Peterman, 2013) (Table 4).

Table 4. Population estimates and densities of salamander species that inhabit caves or similar habitat (i.e., springhouses and rock faces).

\begin{tabular}{cccc}
\hline Source & Species & Population Estimate & Density (salamanders m $^{-2}$ ) \\
\hline Salvido (1998) & Hydromantes [Speleomantes] strinatii & 155 & 0.8 \\
Huntsman et al. (2011) & Gyrinophilus palleucus & 109,215 & $0.03 \& 0.10$ \\
Crawford and Peterman (2013) & Desmognathus spp. & 496 & 14.69 \\
Fenolio et al. (2014) & Eurycea spelaea & 342,507 & $0.04 \& 0.12$ \\
Nazdrowicz (2015) & Eurycea longicauda & $29-1410$ & $\ldots$ \\
Taylor et al. (2015) & Plethodon albagula & 157 & $0.61-1.14$ \\
\hline
\end{tabular}

Our highest seasonal abundance estimates, which occurred in spring 2016, followed by summer of both years, generally reflect trends that others have found for E. lucifuga, with monthly (May to June: Hutchison, 1958; May: Williams, 1980) or seasonal (spring: Camp et al., 2014; summer: Briggler and Prather, 2006) highest counts and average counts similarly reported at these times. These earlier authors studied Cave salamanders in the twilight zone of their study caves, and given that Cave salamanders predominantly reside in this area of caves in spring and summer (Hutchison, 1958; Williams, 1980) it is unsurprising that their studies found highest abundance then.

In our study, the lowest seasonal abundance occurred in spring 2015, which is probably atypical for the spring season. Two factors, flooding and temperature, may account for this discrepancy. A substantial flood (ca. $17.3 \mathrm{~cm}$ rainfall in two days) occurred in April 2015 that likely explains the low counts of salamanders in subsequent surveys that month (Fig. 3) because salamanders probably retreated to other areas of the cave or were flushed out; this, undoubtedly, affected abundance estimates for spring 2015. Furthermore, average temperature in February and March of $2015(-3.2$ and $6.9^{\circ} \mathrm{C}$, respectively) for Louisville, Kentucky was lower than the central state average (3.4 and $8.2^{\circ} \mathrm{C}$, respectively), and lower that year than in 2016 (3.9 and $11^{\circ} \mathrm{C}$, respectively) (UKAWC,

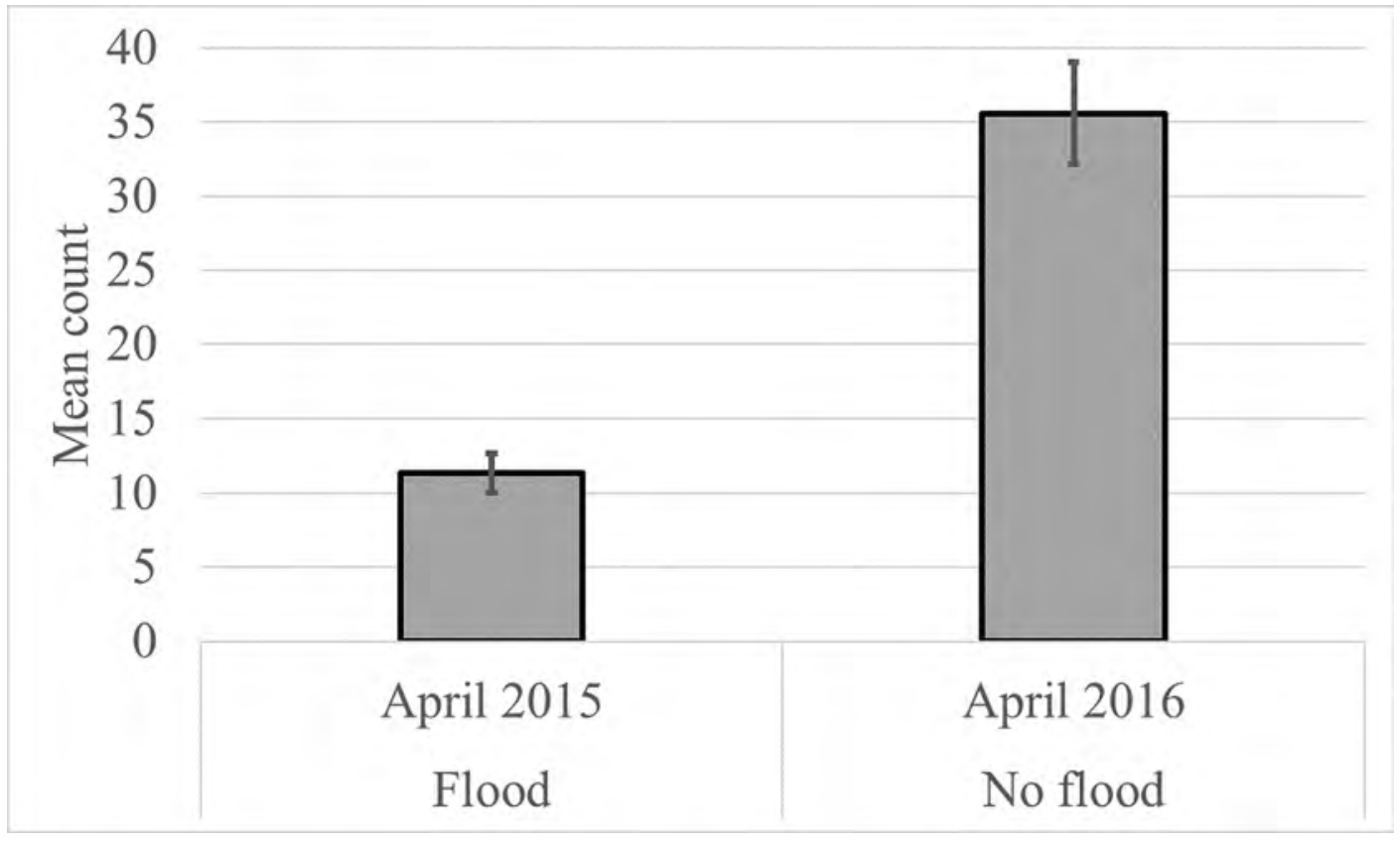

Figure 3. Mean counts $( \pm$ SE) of Cave salamanders in Sauerkraut Cave in April 2015, when there was a substantial flood, and April 2016, when there was no substantial flood. 
2017). This may have influenced the distribution and activity of Cave salamanders within the cave, especially in the twilight zone, where surface environmental fluctuations are most apparent. Our next lowest abundance estimate was in fall 2016. In two studies that focused on the twilight zone, the lowest counts for this species were reported in winter (Hutchison, 1958; Camp et al., 2014); Cave salamanders are rarely found in the twilight zone of caves during winter because the population has moved to the dark zone to escape the inhospitable (i.e., cold and dry) environment near the cave entrance (Hutchison, 1958; Williams, 1980). In a third study that also found the lowest counts in winter, Briggler and Prather (2006) likely surveyed the dark zone of some study caves, but it is unclear how many of their study caves included the dark zone or how far they penetrated. It is uncertain why low abundance occurred in fall in our study, but this result may be associated with low survival probabilities (discussed below).

Capture probabilities for salamanders are generally low due to reduced levels of detectability (O'Donnell and Semlitsch, 2015) and have been shown to vary temporally for both epigean (Bailey et al., 2004; Price et al., 2012; Muncy et al., 2014) and hypogean (Fenolio et al., 2014) species. As expected, capture probabilities in our study were also low and variable, being lowest in spring 2015 and 2016. Cave salamanders often leave caves in spring to explore adjacent epigean habitats for foraging or may emigrate (Petranka, 1998), thus being unavailable for capture in the cave. High capture probability occurred in fall and winter of 2015 and was highest in fall 2016. Cave salamanders reinvade deeper portions of the twilight zone for courtship and/or to escape approaching inhospitable climate at these times of year (Hutchison, 1958; Williams, 1980; Petranka, 1998), making them relatively accessible for capture in the cave.

Our estimates of survival probability are generally similar to those reported for other plethodontids (Price et al., 2012; Fenolio et al., 2014; Muncy et al., 2014). The low probabilities of survival we observed during the fall of both study years may be due to decreasing food availability as salamanders move farther back into the dark zone and to movement of potential predators into the cave for eventual torpor (e.g., Black rat snakes [Pantherophis (Elaphe) obsoleta] and Green frogs [Rana (Aquarana) clamitans] were seen in Sauerkraut Cave in fall). We observed an anecdotal increase in individual tail loss in this season, which may have been a result of interactions with these potential predators. Highest survival probability occurred in spring and summer 2015 and in spring 2016, in seasons when epigean and twilight zone climates are equitable and food is readily available.

Total biomass and biomass density of cave-inhabiting salamanders have seldom been reported. Huntsman et al. (2011) reported biomass density for a troglobitic species as $0.18 \mathrm{~g} \mathrm{~m}^{-2}$ and $0.03 \mathrm{~g} \mathrm{~m}^{-2}$ ash-free dry mass in two caves in Alabama, USA. Salvidio (1998) reports average total wet-biomass and wet-biomass density for a facultative cave-dwelling salamander in Liguria, Italy as $238.48 \mathrm{~g}$ and $1.25 \mathrm{~g} \mathrm{~m}^{-2}$, respectively. An assemblage of Desmognathus spp. at a wet rock face (a similar habitat to caves, albeit likely having higher food densities), had estimated wet-biomass of $916.56 \mathrm{~g}$ and wet-biomass density of $27.16 \mathrm{~g} \mathrm{~m}^{-2}$ (Crawford and Peterman, 2013), respectively, in North Carolina, USA. Our study indicates seasonally variable wet-biomass in this population of Cave salamanders, which likely has important implications for energy distribution within the cave. Dead individuals were rarely observed (nine in total for the study period), but those that were seen were occupied by invertebrates, and all but vertebrae were gone the following survey one week later. Given this short amount of time that dead individuals may be visible before being consumed, and that we could not survey the entire cave, it is likely that more individuals died in the cave without being noticed. This may represent an important pulse nutrient resource for cave-inhabiting organisms. Salamanders may also supply energy through fecal deposition (Bohonak and Whiteman, 1999; Lilleskov and Bruns, 2005) in caves, and we regularly observed salamander feces in Sauerkraut Cave in spring. This contribution may be substantial with greater levels of population biomass.

Salamander densities have been reported for troglobites (Huntsman et al., 2011; Fenolio et al., 2014) and facultative cave dwellers (Salvidio, 1998; Crawford and Peterman, 2013; Taylor et al., 2015) (Table 4). Our densities are most similar to densities reported for troglobitic species (Huntsman et al., 2011; Fenolio et al., 2014), likely because our study took place exclusively within a cave system. Although Taylor et al. (2015) similarly investigated a population of facultative cave-dwelling salamanders in a cave system, they mention that individuals often congregated in a pit, which may have inflated density estimates; our highest density estimate $\left(0.47 \mathrm{~m}^{-2}\right)$ approaches their lowest $\left(0.61 \mathrm{~m}^{-2}\right)$. Densities of those populations studied at rock faces (Salvidio, 1998; Crawford and Peterman, 2013) were higher than our estimates, which may be due to the limited surface area and probable higher food abundance of this habitat compared to a cave system. Rock outcrops are important habitat for many fauna (Fitzsimons and Michael, 2017) and may provide an accessible, safer refuge than what can be found on the ground, making this ideal habitat for salamanders. Likewise, many individuals may utilize this habitat, trading off space for safety, which may explain increased densities at rock faces.

\section{Conclusion}

There is much yet to be learned about the natural history and ecology of Eurycea lucifuga, and facultative cave-dwelling salamanders in general. It is likely, though not well established, that these cave inhabitants play important ecological roles in cave ecosystems. This is an important consideration as caves, and the organisms restricted to them, are 
often of conservation concern. Unraveling the ecological dynamics of facultative cave-dwelling salamanders will surely provide valuable information that can be used to manage and conserve these fascinating habitats.

\section{Acknowledgements}

We thank Paige Wilson, Danica Shepherd, Faith Bowers, and Nick Callahan for assistance in data collection and the developers of Rcapture, Sophie Baillargeon and Louis-Paul Rivest, for their timely explanations and help with R. We thank the staff at E.P. "Tom" Sawyer State Park for facilitating this research. Procedures for handling salamanders were reviewed and approved by the University of Louisville Institutional Animal Care and Use Committee (IACUC \#17005). This study was approved by Kentucky Department and Fish and Wildlife (permit \# SC1711045) and the Kentucky Department of Parks (permit \# 1412).

\section{References}

Bailey, L.L., Simons, T.R., Pollock, K.H., 2004, Comparing population size estimators for plethodontid salamanders: Journal of Herpetology, v. 38, no. 3, 370-380. https://dx.doi.org/10.1670/194-03A.

Baillargeon, S., Rivest, L.-P., 2007, Rcapture: Loglinear models for capture-recapture in R: Journal of Statistical Software, v. 19 , no. 5, 1-31. https://doi.org/10.1.1.168.1620.

Barr, Jr., T.C., 1968, Cave ecology and the evolution of troglobites: pp. 35-102 in T. Dobzhansky, M. K. and Hecht, W. C. Steere, eds., Evolutionary Biology. Boston, Springer.

Barr, Jr., T.C., and Holsinger, J.R., 1985, Speciation in cave faunas: Annual Review of Ecology and Systematics, v. 16, p. 313-337. doi:10.1146/ annurev.es.16.110185.001525.

Beck, H., Snodgrass, J.W., Thebpanya, P., 2013, Long-term exclosure of large terrestrial vertebrates: Implications of defaunation for seedling demographics in the Amazon rainforest: Biological Conservation, v. 163, 115-121. https://doi.org/10.1016/j.biocon.2013.03.012.

Bohonak, A.J., Whiteman, H.H., 1999, Dispersal of the fairy shrimp Branchinecta coloradensis (Anostraca): Effects of hydroperiod and salamanders: Limnology and Oceanography, v. 44, no. 3, 487-493. https://doi.org/10.4319/lo.1999.44.3.0487.

Bradley, J.G., Eason, P.K., 2018, Use of a non-invasive technique to identify individual Cave Salamanders, Eurycea lucifuga: Herpetological Review, v. 49, no. 4, 660-665

Briggler, J.T., Prather, J.W., 2006, Seasonal use and selection of caves by Plethodontid salamanders in a karst area of Arkansas: The American Midland Naturalist, v. 155, no. 1, 136-148. https://doi.org/10.1674/0003-0031(2006)155[0136:SUASOC]2.0.CO;2.

Camp, C.D., Wooten, J.A., Jensen, J.B., Bartek, D.F., 2014, Role of temperature in determining relative abundance in cave twilight zones by two species of lungless salamander (family Plethodontidae): Canadian Journal of Zoology, v. 92, 119-127.. https://doi.org/10.1139/cjz-2013-0178.

Carlyle, J.C., Sanders, D.E., Plummer, M.V., 1998, Eurycea lucifuga (Cave Salamander). Reproduction: Herpetological Review, v. 29, no. 1, 37-38.

Crawford, J.A., Peterman, W.E., 2013, Biomass and habitat partitioning of Desmognathus on wet rock faces in the southern Appalachian mountains: Journal of Herpetology, v. 47, no. 4, 580-584. https://doi.org/10.1670/13-044.

Davic, R.D., Welsh, H.H., 2004, On the ecological roles of salamanders: Annual Review of Ecology, Evolution, and Systematics, v. 35, 405-434. https://doi.org/10.1146/annurev.ecolsys.35.112202.130116.

Fenolio, D.B., Niemiller, M.L., Bonnett, R.M., Graening, G.O., Collier, B.A., Stout, J.F., 2014, Life history, demography, and the influence of cave-roosting bats on a population of the Grotto salamander (Eurycea spelaea) from the Ozark plateaus of Oklahoma (Caudata: Plehodontidae): Herpetological Conservation and Biology, v. 9, no. 2, 394-405. https://doi.org/10.1146/annurev.ento.51.110104.151107.

Fitzsimons, J.A., Michael, D.R., 2017, Rocky outcrops: A hard road in the conservation of critical habitats: Biological Conservation, v. 211, 36-44. https://doi.org/10.1016/j.biocon.2016.11.019.

Ford, H.A., Ford, K., 1882, Anchorage: Page 33 in History of the Ohio falls cities and their counties, v. 2. Cleveland, Ohio, USA, L. A. Williams \& Co.

Green, N.B., Brant Jr., P., Dowler, B., 1967, Eurycea lucifuga in West Virginia: Its distribution, ecology, and life history: Proceedings of the West Virginia Academy of Science, v. 39, 297-304.

HACC: Herpetological Animal Care and Use Committee, 2004, Guidelines for use of live amphibians and reptiles in field and laboratory research, 2nd Ed: American Society of Ichthyologists and Herpetologists.

Hairston Sr., N.G., 1987, Community ecology and salamander guilds: Cambridge, England, UK, Cambridge University Press, 230 p.

den Hartog, J., Reijns, R., 2014, I3S Spot Manual: Interactive Individual Identification System version 4.0.2: http://www.reijns.com/i3s/download/ I3S Spot.pdf. [accessed February 20, 2015].

Huntsman, B.M., Venarsky, M.P., Benstead, J.P., Huryn, A.D., 2011, Effects of organic matter availability on the life history and production of a top vertebrate predator (Plethodontidae: Gyrinophilus palleucus) in two cave streams: Freshwater Biology, v. 56, 1746-1760. https://doi. org/10.1111/j.1365-2427.2011.02609.x.

Hutchison, V.H., 1958, The distribution and ecology of the cave salamander, Eurycea lucifuga: Ecological Monographs, v. 28, no. 1, 1-20. https:// doi.org/10.2307/1942273.

Hutchison, V.H., 1966, Eurycea lucifuga: Catalogue of American Amphibians and Reptiles, v. 24.1, 24.1-24.2.

Jonas, M., Bowman, J.L., Nazdrowicz, N.H., 2011, Using spot pattern to identify individual long-tailed salamanders: Herpetological Review, v. 42, no. $4,520-522$.

Juterbock, J.E., 2005, Eurycea lucifuga Rafinesque, 1822, Cave Salamander: Pages 750-753 in M. Lannoo, ed. Amphibian Declines: The Conservation Status of United States Species. Berkeley, California, USA, University of California Press.

Lanza, B., Pastorelli, C., Laghi, P., Cimmaruta, R., 2006, A review of systematics, taxonomy, genetics, biogeography and natural history of the genus Speleomantes Dubois, 1984 (Amphibia Caudata Plethodontidae): Atti del Museo Civico di Storia Naturale di Trieste, v. 52, p. 5-135.

Lilleskov, E.A., Bruns, T.D., 2005, Spore dispersal of a resupinate ectomycorrhizal fungus, Tomentella sublilacina, via soil food webs: Mycologia, v. 97, no. 4, 762-769. https://doi.org/10.1080/15572536.2006.11832767.

Lunghi, E., Manenti, R., Ficetola, G.F., 2014, Do cave features affect underground habitat exploitation by non-troglobite species? Acta Oecologica, v. 55, p. 29-35. doi:10.1016/j.actao.2013.11.003. 
Muncy, B.L., Price, S.J., Dorcas, M.E., 2014, Capture probability and survivorship of the Southern two-lined salamander (Eurycea cirrigera) in drought and non-drought conditions: Copeia, v. 2014, no. 2, 366-371. http://doi.org/10.1643/CE-13-139.1.

Nazdrowicz, N.H., 2015, Ecology of the eastern long-tailed salamander (Eurycea longicauda longicauda) associated with springhouses: PhD Dissertation. University of Delaware, Newark, Delaware, USA, $129 \mathrm{p}$.

O'Donnell, K.M., Semlitsch, R.D., 2015, Advancing terrestrial salamander population ecology: The central role of imperfect detection: Journal of Herpetology, v. 49, no. 4, 533-540. https://doi.org/10.1670/14-100.

Petranka, J.W., 1998, Salamanders of the United States and Canada: Washington, DC, USA, Smithsonian Books, 587 p.

Price, S.J., Eskew, E.A., Cecala, K.K., Browne, R.A., Dorcas, M.E., 2012, Estimating survival of a streamside salamander: Importance of temporary emigration, capture response, and location: Hydrobiologia, v. 679, 205-215. https://doi.org/10.1007/s10750-011-0882-2.

R Core Team, 2017, R: A language and environment for statistical computing: Vienna, Austria, R Foundation for Statistical Computing.

Salvidio, S., 1998, Estimating abundance and biomass of a Speleomantes strinatii (Caudata, Plethodontidae) population by temporary removal sampling: Amphibia-Reptilia, v. 19, no. 2, 113-124. https://doi.org/10.1163/156853898X00412.

Schneider, C.A., Rasband, W.S., Eliceiri, K.W., 2012, NIH Image to ImageJ: 25 years of image analysis: Nature Methods, v. 9, no. 7, $671-675$. https://doi.org/10.1038/nmeth.2089.

Semlitsch, R.D., O'Donnell, K.M., Thompson III, F.R., 2014, Abundance, biomass production, nutrient content, and the possible role of terrestrial salamanders in Missouri Ozark forest ecosystems: Canadian Journal of Zoology, v. 92, 997-1004. https://doi.org/10.1139/cjz-2014-0141.

Shaffer, H.B., Alford, R.A., Woodward, B.D., Richards, S.J., Altig, R.G., Gascon, C., 1994, Quantitative sampling of amphibian larvae: pp. 130141 in W. R. Heyer, M. A. Donnelly, R. W. McDiarmid, L.-A. C. Hayek, and M. S. Foster, eds. Measuring and Monitoring Biological Diversity: Standard Methods for Amphibians. Washington, DC, USA, Smithsonian Institution Press.

Sket, B., 2008, Can we agree on an ecological classification of subterranean animals? Journal of Natural History, v. 42, no. 21-22, p. 15491563. doi:10.1080/00222930801995762.

Stasiak, I., 2015, Standard Operating Procedure (SOP): Prevention of disease transmission in amphibians: Kentucky Department of Fish and Wildlife Resources.

Taylor, S.J., Krejca, J.A., Niemiller, M.L., Dreslik, M.J., Phillips, C.A., 2015, Life history and demographic differences between cave and surface populations of the western slimy salamander, Plethodon albagula (Caudata: Plethodontidae), in Central Texas: Herpetological Conservation and Biology, v. 10, no. 2, 740-752.

Trajano, E., Carvalho, M.R., 2017, Towards a biologically meaningful classification of subterranean organisms: A critical analysis of the Schiner-Racovitza system from a historical perspective, difficulties of its application and implications for conservation: Subterranean Biology, v. 22, 1-26. https://doi.org/10.3897/subtbiol.22.9759.

van Tienhoven, A.M., den Hartog, J.E., Reijns, R.A., Peddemors, V.M., 2007, A computer-aided program for pattern-matching of natural marks on the spotted raggedtooth shark Carcharias taurus: Journal of Applied Ecology, v. 44, 273-280. https://doi/10.1111/j.13652664.2006.01273.x.

UKAWC: University of Kentucky Agricultural Weather Center, 2017, Kentucky Climate Data: http://wwwagwx.ca.uky.edu/ky/data.php\#KY_Climate_Data. [accessed February 2, 2017].

Venarsky, M.P., Huntsman, B.M., Huryn, A.D., Benstead, J.P., Kuhajda, B.R., 2014, Quantitative food web analysis supports the energy-limitation hypothesis in cave stream ecosystems: Oecologia, v. 176, no. 3, 859-869. https://doi/10.1007/s00442-014-3042-3.

Williams, A.A., 1980, Fluctuations in a population of the cave salamander Eurycea lucifuga: NSS Bulletin, v. 42, 49-52. 